\title{
Crossing Metacognitive Strategy Awareness in Listening Performance: An Emphasis on Language Proficiency
}

\author{
Ali Dabbagh (Corresponding author) \\ Department of English, Faculty of Humanities, Gonbad Kavous University \\ PO box 163, Gonbad-e-Kavous, Golestan Province, Iran \\ E-mail: dabbaghali@gmail.com \\ Mahdi Noshadi \\ Department of Education \\ Fars Province, Iran \\ E-mail: noshadi_outlandish@yahoo.com
}

Received: 09-06-2014

doi:10.7575/aiac.ijalel.v.3n.6p.234
Accepted: 02-08-2014

Published: 01-11-2014

\begin{abstract}
This paper aims to give a comprehensive account of the roles of metacognitive strategy awareness and proficiency level in EFL Learners' listening comprehension performance. 147 EFL learners were selected and divided into three language proficiency levels according to their scores on Oxford Placement Test (2004). Based on Metacognitive Awareness Listening Questionnaire, they were divided into five groups. To check their listening skill, three listening tests were designed and estimated as both reliable and valid. Besides, a think-aloud procedure was also conducted. The two-way ANOVA demonstrated that: metacognitive listening strategy awareness and language proficiency had independently significant roles in the learners' listening comprehension. Results of post-hoc Scheffe test located a significant role of metacognitive awareness in 'problem-solving' and 'planning-evaluation' groups. Results showed a significant difference in listening performance of elementary-limited and intermediate learners only. The results which promise theoretical and pedagogical implications for language teachers and syllabus designers are fully discussed.
\end{abstract}

Keywords: Metacognitive Awareness; Proficiency Level; Listening Comprehension; Iranian EFL Learners

\section{Introduction}

There are a few reasons why understanding what learners know about learning in general and listening comprehension in particular appears to be of great significance for second language teachers and researchers as well. First, the process and outcome of learning is heavily and directly influenced by what learners know about learning (Palmer \& Goetz, 1988). Second, according to Wenden (1987), learners' awareness and perceptions of learning strategies determine the cognitive complexities of learners which in turn differentiate good and bad learners, and third, there exist few insights about the process of listening comprehension and the way it is learned.

Alongside reading comprehension skill, listening comprehension is one of the significant sources of both second and foreign language learning in terms of input (Rost, 2001). Goh (2000) listed five common listening comprehension problems which students encounter while they are listening. The problems include: a. they quickly forget what is heard; b. they do not recognize words they know; c. they understand words but not the intended message; d. they neglect the next part while thinking about the meaning of the previous one; and e. they are unable to form a mental representation from the words heard. Given this, some unresolved questions arise on how such problems can be eliminated and that whether learners play any role in terms of their knowledge about metacognitive listening strategy or not.

So far, research on listening comprehension has primarily focused on the relationships between schema theory and listening (Babaii, 1996), cognition and listening comprehension (Goh, 2000) and more recently on listening comprehension and strategy use (Graham, Santos, \& Vanderplank, 2008) and listening comprehension and metacognitive strategy instruction (Vandergrift, 2007; Zeng, 2007). However, metacognitive listening strategy awareness has to the best of the researchers' knowledge been deprived of in-depth investigation. As Dornyei (2009) states, learning would happen through certain cognitive processes in the minds of language learners. On the other hand, Vygotsky (as cited in Guo \& Rohering, 2011) believes that learning a foreign language is conscious and deliberate from the onset of the process of learning. Accordingly, what L2 researchers and language teachers should certainly consider is how metacognitive strategy awareness would influence the improvement of L2 listening comprehension performance. Therefore, listening comprehension skill, with a focus on metacognitive strategy awareness, appears to merit further investigation. 


\section{Literature Review}

\subsection{Strategies for listening comprehension}

Early research on listening strategies concentrated inclusively on the learners' awareness of listening strategies as well as on the way the learners could regulate the process of listening comprehension through the application of appropriate strategies (Bacon, 1992, Chamot \& Kupper, 1989, Murphy, 1985). The scope of listening strategy research has recently expanded to focus on learner's cognitive appraisal or meta-cognitive strategy. In the same line, Vandergrift (1997) proposed a framework of strategies for listening comprehension including metacognitive, cognitive, and socio-affective strategies. The first type of strategy refers to mental activities to direct language learning. The second type pertains to mental activities to control the language to achieve a listening task, and still the third one refers to activities including interaction or affective control in learning a language. Selecting those strategies and their degree depend on various factors such as listening task type (Chang, 2008), the usefulness of strategies understood by the learners (Zhang \& Goh, 2006) and learners' attributes including learning style (Liu, 2008), listening ability (Shirani Bidabadi \& Yamat, 2011), the level of language proficiency (Fewell, 2010), and listening anxiety (Golchi, 2012).

Among different types of learning strategies, it seems like metacognitive strategy plays a significant role in foreign language listening skill. O'Malley, Chamot and Kupper (1989) found that second language learners develop their listening skill through the use of monitoring, elaboration and inference, which are all metacognitive learning strategies. In her research on the effect of strategy use and successful listening comprehension, Goh (2000) found that those learners who use metacognitive strategies are more successful at listening comprehension performance. Moreover, she suggested some metacognitive strategies to improve listening comprehension including: a. preview contents in different forms; b. rehearse the pronunciation of potential content words; c. establish a purpose for listening; $d$. listen selectively according to the determined purpose; e. pay attention to discourse markers; f. pay attention to visuals and body language; g. pay attention to tones and pauses; h. monitor comprehension using contexts and prior knowledge; and i. evaluate their comprehension using contexts and prior knowledge.

Also, Graham, Santos and Vanderplank (2008) reported that the use of metacognitive strategy proved to improve students' listening skill. In another study, working on a group of French learners, Vandergrift (2003) found out that learners are different regarding four strategies: 1. metacognitive strategy use; 2. monitoring comprehension; 3. asking for elaboration; and 4. online translation. He also found a greater use of metacognitive strategies at higher proficiency level. Students commented that prediction was so powerful for successful listening and that collaboration with partner worked well for monitoring purposes and finally that using metacognitive approach had a confidence-building role that empower listening comprehension ability (Rost, as cited in Nunan \& Carter, 2001).

\subsection{Metacognitive awareness about listening strategies}

Along with an interest in listening strategy use, listening strategy awareness has also been explored by some researchers. Metacognitive awareness refers to the specialized portion of a learner's acquired knowledge base which consists of what learners know about learning (Wenden, 1999). This awareness may either consciously or unconsciously be acquired. It can be the outcome of imitation, observation, listening to teachers, parents and peers who provide the learner with beneficial advice about how to learn. Accordingly, metacognitive awareness refers to the knowledge of the mental processes including focus on conscious knowledge about learning (Yore \& Treagust, 2006), planning behavior, analysis of the situation the learners are in, and evaluation of the improvement towards learning at the metacognitive level (Wenden, 2002). Metacognitive awareness of listening is recognized as the metacognitive knowledge of the learners' perceptions about themselves, their cognitive objectives, their understanding of the given listening task, their strategies and their approach to the task (Vandergrift, Goh, Mareschal \& Tafaghodtari, 2006). Such strategies involve problem-solving- a group of strategies that listeners use to make inferences and to monitor those inferences; planning and evaluation- strategies that listeners use to prepare themselves for listening and evaluate the results of their listening attempts (Richards, 1990); mental translation- strategies that must be avoided if listeners desire to become skillful listeners (Vandergrift, 2003); person knowledge- the difficulty presented by L2 listening and their self-efficacy in L2 listening (Sparks \& Ganschow, 2001); and directed attention- strategies used to concentrate and stay on a given task (Rost, 2002).

Research on the effectiveness of metacognitive listening strategies awareness has yielded illuminating insights into its role in motivation (Vandergrift, 2005), learning English (Rahimi \& Katal, 2011) and EFL listening technology use (Rahimi \& Katal, 2012). It has also been found that awareness of strategies have a positive effect on listening development (Bolitho, Carter, Hughes, Ivanic, Masuhara, \& Tomlinson, 2003; Wilson, 2003; Victori \& Lockart, 1995). In another study, Vandergrift (2005) explored the effect of raising metacognitive awareness on the listening performance and he found that metacognitive listening knowledge tented to link to listening ability. Goh (2000) argued that a higher degree of awareness of listening problems was demonstrated by more skilled listeners. However, it appears that there exists a dearth of research on the roles of metacognitive strategy awareness and proficiency level in EFL learners' listening comprehension performance. Accordingly, the current study aims to investigate the relationship between metacognitive listening strategy awareness and listening comprehension performance in an EFL context.

In the present study, it is hypothesized that metacognitive listening strategy knowledge has no impact on English language learners' performance on listening comprehension tests; and that proficiency level does not affect listening comprehension skill of Iranian foreign language learners. The following research questions are going to be addressed: 
1. Does metacognitive listening strategy awareness have any impact on English language learners' performance on listening comprehension tests?

2. Does proficiency level affect listening comprehension skill of Iranian foreign language learners?

\section{Methodology}

\subsection{Participants}

To gather data, a sample of 147 elementary-limited, intermediate and proficient-advanced EFL learners were selected based on the results of the Oxford Placement Test (2004). The participants were male and female EFL learners whose age ranged from 18 to 24 years old. They had a background of studying English in a language institute in Iran as well as their mainstream English education in junior and senior high school levels. In order to avoid possible influences of bilingualism (Carson, 1992), the researchers focused solely on the EFL learners who spoke Farsi as their native tongue with no other L1 experience. As a norm, language learners in Iranian institutes are exposed to listening input at least once a session; however, such a focus is absent in the mainstream English education at high schools. The rationale behind selecting such sample was due to the nature of the present study which required participants with a background in listening comprehension activities.

\subsection{Instruments}

A proficiency test, a listening strategy questionnaire and three listening tests were utilized in this study:

\subsubsection{Oxford Placement Test (OPT)}

The overall purpose of implementing such test was to reach at maximum homogeneity among the participants with regard to their language proficiency. In order to assure that participants were at the elementary-limited, intermediate and proficient-advanced levels of English language proficiency, the 2004 version of Oxford Placement Test (OPT) was applied (Table 1). The test consists of 100 listening and 100 grammar questions. The test was reported as both a reliable and valid measurement for language proficiency.

Table 1. Scoring criteria for Oxford Placement Test (OPT) (2004)

\begin{tabular}{cccc}
\hline OPT Band & OPT Score & OPT Language Level & $\begin{array}{c}\text { Number } \\
\text { in each } \\
\text { group }\end{array}$ \\
\hline 0 & Below 75 & Beginner & \\
1 & $80-89$ & False beginner-minimal user & \\
2 & $90-104$ & Basic elementary-limited user & 42 \\
3 & $105-119$ & Elementary-limited user & 52 \\
4 & $120-134$ & Lower intermediate-modest user & 53 \\
5 & $135-149$ & Upper intermediate- competent user & \\
6 & $150-169$ & proficient-advanced user & \\
7 & $170-189$ & Highly proficient-very advanced user & \\
8 & $190-197$ & Professional command-expert user & \\
9 & $198-200$ & Functionally Bilingual &
\end{tabular}

As Kassaian and Esmae'li (2011) reported, the test has been calibrated against the proficiency levels provided by Common European Framework of Reference (CEFR). It should also be mentioned that scores on OPT correlated significantly with Nelson English Language Proficiency Test (NELP), and Michigan English Placement Test (MEPT) (see Khosravi, 2010).

\subsubsection{Metacognitive Awareness Listening Questionnaire (MALQ)}

This questionnaire which was originally constructed and validated by Vandergrift et al. (2006) is made up of 21 items to measure the degree of metacognitive listening strategy awareness. The responses to the items of the questionnaire range from 'strongly agree' (which is given a weight of 1) to 'strongly disagree' (which is given a weight of 6) without a neutral point in order to prevent the respondents from hedging. To validate the questionnaire, the designers of the questionnaire did an explanatory factor analysis of the responses of a large sample $(\mathrm{N}=966)$ of language learners and a confirmatory factor analysis with a different sample $(\mathrm{N}=512)$. The confirmatory factor analysis revealed four main factors: problem solving (6 items), planning and evaluation (5 items), mental translation (3 items), person knowledge (3 items) and directed attention (4 items) that enjoy internal consistency of $0.74,0.75,0.78,0.74$, and 0.68 , respectively in Cronbach's alpha scale (ibid). Results of explanatory and confirmatory factor analysis using an Iranian sample supported the five factor model (Rahimi \& Katal, 2012). The reliability coefficient of 0.82 (Baleghizadeh \& Rahimi, 2011) and 0.85 (Shirani Bidabadi \& Yamat, 2011) have also been reported with Iranian samples. 
As the participants of the study were from all levels of language proficiency, the researchers translated the questionnaire into the participants' native language (i.e. Farsi) so that they would not encounter any difficulties in understanding the items of the questionnaire. The reliability (KR-20) of the translated version of the questionnaire was estimated as 0.79 and that of the English version for the sample of the present study as 0.81 by the researches.

\subsubsection{Listening tests}

Three listening tests, one for each proficiency level, were used in this study. Each test consists of different test formats, namely multiple choice, completion and matching to cover all areas of listening comprehension in each level. Three $\mathrm{PhD}$ holders in Applied Linguistics were asked to review the tests in order to verify the construct validity of the listening tests. Also, the researchers estimated the reliability of each listening tests using KR-20 formula as $0.82,0.93$, 0.87 for elementary-limited, intermediate and proficient-advanced levels, respectively.

\subsubsection{Think-aloud procedure}

The participants were asked to verbalize the thoughts entering into their attention regarding the strategies they used while doing the listening tasks during a three-month course of English learning. This was aimed at providing support for the strategies students reported in MLAQ.

\subsection{Procedure for data collection and data analysis}

In order to ensure about the proficiency of the participants, the Oxford Placement Test (OPT) was initially administered to the participants. Based on the results of the test, 147 EFL learners were nominated as elementary-limited, intermediate and proficient-advanced levels of proficiency. In the next stage of the study, each participant took part in the listening test according to their proficiency level. The listening audios were played for the participants twice. The think-aloud profiles conducted and gathered before administering the Metacognitive Awareness Listening Strategy (MLAQ) with a precise instruction to produce useful data, were recorded and then transcribed by the researchers. The content analysis procedure was followed to determine the similarities and differences between what the participants reported as being aware of in MLAQ and what they themselves claimed to be aware of in the think-aloud procedure. The rationale behind this order of test/questionnaire administration was to prevent the sensitization of the participants in that they were no longer able to change their behavior for or against the results of the study.

The MLAQ papers were scored according to the criteria proposed by Vandergrift, et al. (2006). Based on this scoring key, the items of MALQ were categorized into 5 main groups, namely planning-evaluation (items 1-10-14-20-21), directed attention (items 2-6-12-16), person knowledge (items 3-8-15), mental translation (4-11-18) and problem solving (items 5-7-9-13-17-19). Scoring participants' listening test was done based on the exact answer method to avoid heterogeneity in the resulted scores.

The data obtained from listening tests and MLAQ were analyzed using the two-way ANOVA procedure, with language proficiency and metacognitive listening strategy awareness as independent variables and listening comprehension as the dependent variable.

\section{Results}

In order to have a genuine picture of the participants' awareness of the metacognitive listening strategy, the data gathered in the think-aloud phase went on content analysis. In doing the content analysis, the think-aloud protocols were grouped based on the five metacognitive type scales of Vandergrift et al. (2006), i.e. 'planning evaluation', 'directed attention', 'person knowledge', 'mental translation', and 'problem solving'. Also, to check whether the data gathered in the think-aloud procedure matched the data reported in the Metacognitive Listening Strategy Awareness Questionnaire, the researchers analyzed the questionnaire data and categorized it into two groups of aware and unaware of the strategy according to each metacognitive strategy type scale. The following Table summarizes the results.

Table 2. Participants' awareness of metacognitive listening strategy types (\%)

\begin{tabular}{llllll}
\hline \multirow{2}{*}{ Metacognitive Listening Strategy Type } & \multicolumn{2}{c}{ Aware } & \multicolumn{2}{c}{ Unaware } \\
\cline { 2 - 6 } & $\mathrm{TL}^{\mathrm{a}}$ & $\mathrm{Q}^{\mathrm{b}}$ & 33 & 38 \\
\hline Planning evaluation & 57 & 62 & 37 & 45 \\
Directed attention & 63 & 55 & 28 & 39 \\
Person knowledge & 72 & 61 & 66 & 72 \\
Mental translation & 34 & 28 & 74 & 69 \\
Problem solving & 26 & 31 & & $\mathrm{TL}$ \\
\hline
\end{tabular}

a: think-aloud $\quad$ b: questionnaire

As follows from the above Table, the participants' awareness or unawareness of the metacognitive listening strategy type in think-aloud protocols and questionnaire results matches with a little difference between the two. The Table also indicates that most of the participants were aware of the metacognitive listening strategy they might use while doing the listening tasks. 
Among the participants whose think-aloud protocol analysis showed awareness of metacognitive listening strategy, some reported the following:

"I try to have a quick look at the task before listening [...] this gives me some information about the topic that I will be listening to. In this way, I may have less stress and can manage my listening. I mean, I can choose what to focus and what not to focus on." (think-aloud profile No. 45)

"Sometimes I think about the topic of the listening task and remember what I know about it. In this way, I remember some related words I know. While listening, I am a bit critical of myself. I am always in doubt that I have understood correctly or not. This question has always been with me." (think-aloud profile No. 36)

However, some of the participants who were unaware of the metacognitive listening strategy, either they use it in doing the listening tasks or not, had the following ideas:

"In doing the listening tasks, I just look at the questions, read them and listen to find out the answer. I think that's enough to have a good score." (think-aloud profile No. 130)

"Sometimes I have difficulty in listening. I do not understand them. Sometimes they are fast, sometimes they contain words I don't know, and sometimes the task is very difficult. At these moments I don't know what to do. My mind stops and I become so much stressed." (think-aloud profile No. 56)

As indicated earlier, the participants were divided into five groups of metacognitive listening strategy factors. Consider Table 3 which presents the distribution of the participants in these five groups according to proficiency levels.

Table 3. Distribution of participants based on the results of MLAQ and proficiency test

\begin{tabular}{lll}
\hline Level & Metacognitive Factor & N \\
\hline \multirow{2}{*}{ Elementary-limited user } & Planning-evaluation & 15 \\
& Directed attention & 10 \\
& Person knowledge & 2 \\
& Mental translation & 8 \\
& Problem solving & 7 \\
Intermediate & Planning-evaluation & 13 \\
& Directed attention & 12 \\
& Person knowledge & 1 \\
& Mental translation & 14 \\
& Problem solving & 12 \\
Proficient-advanced user & Planning-evaluation & 17 \\
& Directed attention & 14 \\
& Person knowledge & 2 \\
& Mental translation & 10 \\
& Problem solving & 10 \\
\hline
\end{tabular}

In order to probe the null hypotheses predicting no significant role of metacognitive listening strategy awareness and proficiency level in EFL learners' listening comprehension, a two-way ANOVA was run with metacognitive strategy awareness and proficiency level as the independent variables and listening comprehension as the dependent one. Table 4 presents the overall results for the proficiency level, metacognitive listening strategy awareness and the interaction of the two.

Table 4. Results of two-way ANOVA: Tests of between-subjects effects

\begin{tabular}{lllll}
\hline Source & df & Mean Square & F & Sig. \\
\hline MLSA & 3 & 10.098 & 2.978 & $.047^{*}$ \\
Proficiency Level & 2 & 13.333 & 3.932 & $.030^{*}$ \\
MLSA * Proficiency Level & 5 & 2.938 & .867 & $.515^{\mathrm{a}}$ \\
\hline
\end{tabular}

*: significant at .05 a: not significant at .05

MLSA: Metacognitive Listening Strategy Awareness

As it is clear from Table 4, metacognitive listening strategy awareness and proficiency level have significant roles in listening comprehension independently $(\mathrm{F}=2.978, \mathrm{p}=0.47 . \mathrm{p}>.05$ and $\mathrm{F}=3.932, \mathrm{p}=.030, \mathrm{p}>0.5$, respectively); however, such significance was not observed for the interaction of the two $(F=2.938, p=.515, p<.05)$. Therefore, the null hypotheses were only partially rejected. 
To find out where the differences between the five factors of metacognitive listening strategy awareness and the listening comprehension skill lies, a Scheffe test was performed. As Table 5 shows the difference was significant between 'problem solving' and 'planning-evaluation' groups $(\mathrm{p}=0.17, \mathrm{p}>.05)$, while no significant difference was observed between other levels.

Table 5. Scheffe test for the metacognitive factors

\begin{tabular}{lllll}
\hline \multicolumn{1}{c}{ Metacognitive factor (i) } & \multicolumn{1}{c}{ Metacognitive factor $(\mathrm{j})$} & \multicolumn{1}{c}{$\begin{array}{c}\text { Mean } \\
\text { Difference }\end{array}$} & Std. Error & \\
& & & \\
& & 1.3750 & .8275 & .442 \\
Planning evaluation & Directed attention & -.2000 & .9690 & .998 \\
& Mental translation & $2.3750^{*}$ & .6876 & .017 \\
& Problem solving & -1.3750 & .8275 & .442 \\
Directed attention & Planning evaluation & -1.5750 & 1.0498 & .530 \\
& Mental translation & 1.0000 & .7974 & .669 \\
& Problem solving & .2000 & .9690 & .998 \\
Mental translation & Planning evaluation & 1.5750 & 1.0498 & .530 \\
& Directed attention & 2.5750 & .9435 & .079 \\
& Problem solving & $-2.3750^{*}$ & .6876 & .017 \\
Problem solving & Planning evaluation & -1.0000 & .7974 & .669 \\
& Directed attention & -2.5750 & .9435 & .079 \\
\hline
\end{tabular}

*: The mean difference is significant at the .05 level

To find out the exact differences in proficiency levels regarding listening comprehension skill, a Scheffe test was applied to the data. From Table 6 it can be seen that there is a significant difference between elementary-limited and intermediate levels, while no significant difference was found between elementary-limited and proficient-advanced and between intermediate and proficient-advanced levels. This means that 'problem solving' and 'planning-evaluation' are of metacognitive listening strategy awareness that can be much useful in improving listening comprehension skill of foreign language learners.

Table 6. Scheffe test for proficiency level

\begin{tabular}{|c|c|c|c|c|c|}
\hline Proficiency level (i) & Proficiency level (j) & Mean Difference & & Std. Error & Sig. \\
\hline Elementary-limited & Intermediate & $-2.4762^{*}$ & & .7244 & .007 \\
\hline & Proficient-Advanced & -.9583 & & .7032 & .406 \\
\hline Intermediate & Elementary-limited & $2.4762^{*}$ & & .7244 & .007 \\
\hline & Proficient-Advanced & 1.517 & & .6739 & .095 \\
\hline Proficient-Advanced & Elementary-limited & .9583 & & .7032 & .406 \\
\hline & & & .6739 & & \\
\hline
\end{tabular}

*: The mean difference is significant at the .05 level

\section{Discussion}

The current study addressed the roles of metacognitive strategy awareness and proficiency level in EFL learners' listening comprehension performance. Consequently, two null hypotheses were proposed earlier rejecting such effects.

Our results are a contribution to the ongoing discussions about metacognitive strategy awareness in the field. They confirmed that metacognitive listening strategy awareness contributes significantly to listening comprehension of EFL learners. This floats the idea that metacognitive awareness about specific activities directs learners on how to approach a listening task (Coskun, 2010; O'Bryan \& Hegelheimer, 2009) and helps them to uncover the mental process that happens inside their head when they listen (Goh, 2008). This finding supports the results of the other studies in the literature (Vandergrift, 2007; Vandergrift, 2005; Wilson, 2003; Victori \& Lockart, 1995). Also, literature shows that metacognitive strategy use enhances second language learners' listening comprehension (Goh, 2000; O'Malley et al., 1989) and that categorization of the manner in which strategy use is carefully arranged while listening sensitizes language learners to the process underlying listening (Vandergrift \& Tafaghodtari, 2010). This, taking the results of the present study into consideration, suggests that both metacognitive strategy use and metacognitive strategy awareness can improve listening comprehension skill. 
The findings revealed that 'problem solving' and 'planning-evaluation' are areas of metacognitive strategy awareness that can be much useful than other areas in improving listening comprehension skill of foreign language learners. It is probable that raising learners' awareness of such strategies can enhance their listening comprehension. In this regard, a few studies have revealed mixed findings on the effect of metacognitive awareness instruction on listening performance. Vandergrift and Tafaghodtari, (2010); Coskun (2010); O'Bryan and Hegelheimer, (2009); Mareschal, (2007) reported a positive effect of metacognitive awareness instruction on listening comprehension, while in their studies, Chen and Haung, (2011) and Ozeki, (2000) and found no immediate effect of metacognitive awareness instruction on the improvement of listening performance. Such non-significant difference in listening performance may pertain to the learners' proficiency in listening comprehension or even the methodology adapted for teaching the listening tasks.

Results obtained from the present study indicated that proficiency level played a significant role in listening comprehension skill of Iranian foreign language learners. It was observed that there was a significant difference between elementary-limited and intermediate level, while no significant difference was found between elementary and advanced and between elementary-limited and proficient-advanced levels. This result is in good agreement with other studies conducted by Cross (2010); Vandergrift and Tafaghodtari (2010) and Mareschal (2007) who found that low proficiency listeners benefit more from instructing listening strategies than advanced listeners because according to Cross (2010), beyond the threshold level for advanced listeners, the impact of metacognitive awareness would be minimal. However, this result is not consistent with that obtained by Vandergrift (2004) in terms of metacognitive strategy use. He found that higher proficiency level learners use metacognitive strategy much more than other levels. The most likely explanation of such contradiction is that the story is different when it comes to awareness of metacognitive strategy and it works better in lower proficiency level than the higher ones since proficient listeners "had already reached a comparatively solid level of understanding and orchestration of bottom-up and top-down skills and strategies" (Cross, 2010, p.7). However, this issue is open to further research in EFL settings because the relationship between language proficiency and strategy awareness is a very complicated issue. In addition, no interaction was found between metacognitive listening strategy awareness and proficiency level. This means that the effect of metacognitive listening strategy awareness on listening comprehension will not change across different proficiency levels. It can be inferred that metacognitive listening awareness and proficiency have their effects independently on listening comprehension and may not affect each other in terms of contributing to listening comprehension.

\section{Conclusion}

The present paper aimed to investigate the roles metacognitive strategy awareness and proficiency level play in EFL learners' listening comprehension performance. From the outcome of our investigation, it is possible to conclude that metacognitive listening strategy awareness could enhance EFL learners' listening comprehension skill. Also, it is evident that two types of metacognitive listening strategy awareness i.e. 'problem solving' and 'planning-evaluation' were found to play a significant role in improving listening comprehension skill of foreign language learners.

As for the pedagogical implication of the study, the findings suggest that listening curriculum developers and course designers may put increasing emphasis on awareness of metacognitive listening strategies to enrich their programs. The findings are of direct practical relevance to material developers who may include more sections related to metacognitive listening strategies in listening course books with an emphasis on raising learners' awareness of such strategies, especially in lower levels. Apparently, there is a great deal more to be found out about metacognitive listening strategy awareness. Further research will involve in investigating whether the learners who are aware of their metacognitive listening strategy also use it while engaging in listening comprehension, especially in 'planning-evaluation' and 'problem solving' or not. Another issue that merits research is the impact of gender of the language learners in this domain. Accordingly, a similar study can be conducted with taking this as one independent variable into consideration. The issue could be investigated further by examining the effects of the awareness of metacognitive strategy on other language skills. Since the participants of the present study were between 18 and 27 years old, a similar study on participants of different age range might bring interesting or perhaps different results. Further research into metacognitive strategy awareness is desirable to extend our knowledge of the mechanisms involved in the improvement of listening comprehension performance of our EFL learners.

\section{References}

Babaii, E. (1996). On the Incompability of Schema with Input in Listening Comprehension. Unpublished master thesis. Teacher Training University.

Bacon, S. M. (1992). The relationship between gender, comprehension, processing strategies, and cognitive and affective response in foreign language listening. The Modern Language Journal, 76(2), 160-178.

Baleghizadeh, S. \& Rahimi, A. H. (2011). The Relationship among listening performance, metacognitive strategy use and motivation from a self-determination theory perspective. Theory and Practice in Language Studies, 1(1), 61-67.

Bolitho, R., Carter, R., Hughes, R., Ivanic, R., Masuhara, H., \& Tomlinson, B. (2003). Ten questions about language awareness. ELT Journal, 57(3), 251-260.

Carson, J.G.(1992). Becoming biliterate: first language influences. Journal of Second Language Writing, 1, 37-60.

Carter, R. \& Nunan D. (2001). The Cambridge Guide to Teaching English to Speakers of Other Languages: Cambridge: Cambridge University Press. 
Chamot, A. U. \& Kupper, L. (1989). Learning strategies in foreign language instruction. Foreign Language Annals, 22(1), 13-24.

Chang, A.C.S. (2008). Listening strategies of L2 learners with varied test tasks. TESL Canadian Journal, 25(2), 1-26.

Chen, C. C. \& Huang, C. T. (2011). Raising EFL college students' metacognitive awareness about listening. Paper presented at the NYSTESOL 41st Annual Conference, Melville, NY.

Coskun, A. (2010). The effect of metacognitive strategy training on the listening performance of beginner students. Novitas-ROYAL (Research on Youth and Language), 4(1), 35-50.

Cross, J. (2010). Metacognitive instruction for helping less-skilled listeners. ELT Journal, 65(4), 408-416.

Dornyei, Z. (2009). The psychology of second language acquisition. New York: Oxford University Press.

Fewell, N. (2010). Language learning strategies and English language proficiency: An investigation of Japanese EFL university students. TESOL Journal, 2, 159-174.

Graham, S., Santos, D., Vanderplank, R. (2008). Listening comprehension and strategy use: A longitudinal exploration. System 36, 52-68.

Goh, C. (2000). A cognitive perspective on language learners' listening comprehension problems. System, 28(1), 55-75.

Goh, C. (2008). Metacognitive instruction for second Language listening development: Theory, practice and research implications. RELC Journal, 39(2), 188-213.

Golchi, M.M. (2012). Listening anxiety and its relationship with listening strategy use and listening comprehension among Iranian IELTS learners. International Journal of English Linguistics, 2(4), 115-128.

Guo, Y., \& Roehrig, A. D. (2011). Roles of general versus second language (L2) knowledge in L2 reading comprehension, Reading in a Foreign Language, 23(1), 42-64.

Kassaian, Z., \& Esmae'li, S. (2011). The effect of bilinguality on L3 breadth of vocabulary knowledge and word reading skill. Theory and Practice in Language Studies, 1(8), 966-974.

Khosravi, A. (2010). Using bilingual dictionaries in L2 learners 'writing tests.(Unpublished master's thesis). Islamic Azad University, Najaf Abad Branch, Iran.

Liu, H.J. (2008). A study of the interrelationship between listening strategy use, listening proficiency levels, and learning style. ARECLS, 5, 84104.

Mareschal, C. (2007). Student perceptions of a self-regulatory approach to second language listening comprehension development. Unpublished $\mathrm{PhD}$ thesis, University of Ottawa, Canada.

Murphy, J. (1985). An investigation into the listening strategies of ESL college students. ERIC Document Reproduction Service No. ED 2782751

O’Bryan, A. \& Hegelheimer, V. (2009). Using a mixed methods approach to explore strategies, metacognitive awareness and the effects of task design on listening development. Canadian Journal of Applied Linguistics, 12(1), 938.

O'Malley, J. M., Chamot, A. U., \& Kupper, L. (1989). Listening comprehension strategies in second language acquisition. Applied Linguistics, 10(4), 418-437.

Oxford Placement Test (2004). Oxford: Oxford University Press.

Ozeki, N. (2000). Listening strategy instruction for female EFL college students in Japan. Unpublished $\mathrm{PhD}$ dissertation, Indiana University of Pennsylvania.

Palmer, D. J., \& Goetz, E. T. (1988). Selection and use of study strategies: The role of the studier's beliefs about self and strategies. In C. E. Weinstein, E. T. Goetz, \& P. Alexander (Eds.), Learning and study strategies: Issues in assessment, instruction, and evaluation (pp. 77-100). Orlando, FL: Academic Press.

Rahimi, M. \& Katal, M. (2011). Iranian university students' metacognitive listening strategies awareness in learning English. Paper presented at the Third National Conference on Education. SRTTU, Tehran, Iran.

Rahimi, M. \& Katal, M. (2012). The role of metacognitive listening strategies awareness and podcast-use readiness in using podcasting for learning English as a foreign language. Computers in Human Behavior, 28(4), 1153-1161. Richards, J.C. (1990). The language teaching matrix. Cambridge, UK: Cambridge University Press.

Rost, M. (2001). Listening. In Carter, C. \& Nunan, D. (Eds). The Cambridge Guide to Teaching English to Speakers of Other languages. Cambridge: CUP

Rost, M. (2002). Listening, In R Carter \& D. Nunan (Eds.). The Cambridge guide to teaching English to speakers of other languages (pp.7-13). Cambridge: Cambridge University Press.

Shirani Bidabadi, F. \& Yamat, H. (2011). The Relationship between listening strategies used by Iranian EFL freshman university students and their listening proficiency levels. English Language Teaching, 4(1), 26-32

Sparks, R., \& Ganschow, L. (2001). Aptitude for learning a foreign language. Annual Review of Applied Linguistics, 21, 90-112.

Vandergrift, L. (1997). The comprehension strategies of second language(French) listeners: A descriptive study. Foreign Language Annals, 30(3), 387-409.

Vandergrift, L. (2003). Orchestrating strategy use: Toward a model of the skilled second language listener. Language Learning, 53(3), 463-496.

Vandergrift, L. (2004). Listening to learn or learning to listen? Annual Review of Applied Linguistics, 24, 3-25.

Vandergrift, L. (2005). Relationships among motivation orientations, metacognitive awareness and proficiency in L2 listening. Applied Linguistics, 26(1), 70-89.

Vandergrift, L. (2007). Teaching learners how to listen does make a difference. Paper presented at the meeting of the Canadian Association of Applied Linguistics.

Vandergrift, L., Goh, C., Mareschal, \& Tafaghodtari, M. H. (2006). The metacognitive awareness listening questionnaire (MALQ): Development and validation. Language Learning, 56(3), 431-462.

Vandergrift, L. \& Tafaghodtari, M. (2010). Teaching L2 learners how to listen does make a difference: An empirical study. Language Learning, 60(2), 470-97. 
Victori, M., \& Lockhart, W. (1995). Enhancing metacognition in self-directed language learning. System, 23, 223-234. Vygotsky, L. S. (1962). Thought and Language. Cambridge MA: MIT Press.

Wenden, A. (1987). Metacognition: An expanded view on the cognitive abilities of L2 learners. Language Learning: 37(4): 573-95.

Wenden, A. (1999). An Introduction to Meta-cognitive Knowledge and Beliefs in Language Learning: Beyond the Basics. System, 25, pp. 435-441

Wenden, A. L. (2002). Learner development in language learning. Applied Linguistics, 23(1), 32-55.

Wilson, M. (2003). Discovery listening: Improving perceptual processing. ELT Journal, 57, 335-343.

Yore. L. D., \& Treagust, D. F. (2006). Current realities and future possibilities: Language and science literacyempowering research and informing instruction. International Journal of Science Education, 28(2), 291-314.

Zeng, Y. (2007). Metacognitive instruction in listening: A study of Chinese non-English major undergraduates. Unpublished MA thesis. National Institute of Education, Nanyang Technological University, Singapore.

Zhang, D. \& Goh, C. (2006). Strategy knowledge and perceived strategy use: Singaporean students' awareness of listening and speaking strategies. Language Awareness, 15(3), 199-221. 